\title{
Immunofluorescence in duodenal mucosa of children with acute enteritis due to a new virus
}

\author{
G. P. DAVIDSON, I. GOLLER, R. F. BISHOP ${ }^{1}$, R. R. W. TOWNLEY, \\ I. H. HOLMES, AND B. J. RUCK
}

From the Departments of Gastroenterology and Pathology, Royal Children's Hospital, Melbourne, and the Department of Microbiology, University of Melbourne, Melbourne, Australia

SYNOPSIS Electron microscopy of duodenal mucosa from children with acute non-bacterial enteritis has shown virus particles in epithelial cells. Indirect immunofluorescent techniques applied to the same tissue showed virus antigen localized in the cytoplasm of epithelial cells of the villi. Specific IgM antibody was present in sera from infected patients as early as two days after the onset of symptoms. Virus particles from different patients appeared to share a common antigen. The evidence presented supports our belief that this new virus was the cause of acute enteritis in the children studied.

Electron microscopy of duodenal mucosa obtained by biopsy of children with acute non-bacterial enteritis has shown virus particles multiplying in epithelial cells (Bishop, Davidson, Holmes, and Ruck 1973a, b). The virus belongs to a newly described group within the family Reoviridae, and the name 'duovirus' has been proposed for this new group (Holmes, Ruck, Schnagl, Bishop, and Davidson, 1975). It is considered to be the aetiological agent of acute enteritis in the children in whom it is observed (Bishop et al, 1973b).

Using the electron microscope, only a minute portion of the available tissue could be searched, and it was difficult to be sure of the localization of infected epithelial cells along the villi. Also, although morphology of virus particles from different patients was identical, no information could be obtained about any similarity of antigenic structure.

For these reasons it was decided to use indirect fluorescent antibody techniques to locate duovirus in portions of duodenal biopsy specimens already shown to contain duovirus by electron microscopy. The results obtained add to our knowledge of the intestinal lesions produced by this virus, and give preliminary information about its antigenic structure and host response to infection.

\footnotetext{
${ }^{1}$ Requests for reprints should be addressed to: Dr R. F. Bishop, Department of Gastroenterology, Royal Children's Hospital, Melbourne, Victoria, Australia, 3052.

Received for publication 7 January 1975.
}

\section{Material and Methods}

This study used duodenal mucosa in which duovirus particles had previously been located by electron microscopy of ultrathin sections (Bishop et al, 1973b). Specimens were available from eight children subjected to duodenal biopsy one to five days after the onset of symptoms of acute enteritis. Histologically normal duodenal mucosa from two children investigated for failure to thrive were used as controls.

Sera were collected from seven children two to four days from the onset of symptoms ('acute' sera) and 14-30 days later ('convalescent' sera). All seven children had shown duovirus particles in duodenal mucosa or faecal extracts (Bishop et al, 1974). Three control sera were obtained from a newborn infant, a child aged 5 months with no history of enteritis, and a healthy adult. All sera from patients and controls were used at 1 in 2 dilutions. In addition, acute and convalescent sera from two patients were used in dilutions over a range 1 in 2 to 1 in 64 .

Duodenal mucosa was processed by a modification of the technique described by Saint-Marie (1962). After initial fixation in $95 \%$ ethanol at $4^{\circ} \mathrm{C}$ for two hours minimum (maximum overnight) the tissue was dehydrated at approximately 10-minute intervals in three successive changes of absolute ethanol at $4^{\circ} \mathrm{C}$ and two changes of xylene, the first at $4^{\circ} \mathrm{C}$, the second at room temperature. Tissue was 
vacuum embedded for five minutes at $60^{\circ} \mathrm{C}$, blocked in paraffin ${ }^{1}$, and stored at $4^{\circ} \mathrm{C}$. Sections $4-6 \mu$ thick were cut and were floated on a $45^{\circ} \mathrm{C}$ water bath for a maximum period of two seconds. Deparaffinization of slides was carried out at $4^{\circ} \mathrm{C}$ in three changes of xylene, two of absolute ethanol, and two of phosphate-buffered saline (PBS) for five to 10 seconds in each bath.

Sections were incubated with serum for 30 minutes at $37^{\circ} \mathrm{C}$ and then washed twice in PBS for 10 minutes. The sections were then incubated with fluorescein-labelled antisera to human immunoglobulin $\mathbf{G}, \mathbf{A}$, or $\mathbf{M}^{2}$ for 30 minutes at room temperature. Slides were washed twice with agitation in PBS for 15 minutes and were mounted in $50 / 50$ PBS/glycerol.

All slides were examined under blue light using a Leitz microscope, a dark ground condenser, with BG 38 and KP 490 excitation filters and an OG1 barrier filter. Slides were coded and read by two independent observers unaware of their source. The results were recorded with a Leitz Orthomat automatic camera.

\section{SPECIFICITY OF IMMUNOFLUORESCENCE}

This was determined by incubating duodenal biopsy tissue containing duovirus with sera absorbed with 'purified' duovirus particles. The duovirus was obtained by differential centrifugation of faeces from a child with acute enteritis (Bishop, Davidson, Holmes and Ruck 1974). To absorb the sera, faecal extract containing duovirus particles was diluted 1 in 2 with PBS, mixed with an equal volume of a 1 in 2 dilution of acute or convalescent serum, incubated for one hour at $37^{\circ} \mathrm{C}$, overnight at $4^{\circ} \mathrm{C}$, and centrifuged at $2000 \mathrm{~g}$ for 15 minutes. The supernatant was incubated with duodenal tissue. Immune aggregates were seen when the deposit was resuspended in 1-2 drops of distilled water, stained with potassium phosphotungstate at $\mathrm{pH} 7 \cdot 0$, and examined with a Hitachi electron microscope.

REACTION WITH REOVIRUS ANTISERA

Duodenal biopsy tissue containing duovirus was incubated with rabbit antisera to reovirus type 1 (Lang strain), type 2 (Jones strain), and type 3 (Abney strain). Fluoresceinated antirabbit gamma globulin was used as the marker.

\section{Results}

Table I lists fluorescence observed in duodenal biopsy tissue incubated with a variety of sera at 1 in 2 dilution. Fluorescence was seen within epithelial

${ }^{1}$ Paraplast plus (melting point $56-57^{\circ} \mathrm{C}$ ) ${ }^{2}$ Hyland Laboratories

\begin{tabular}{|c|c|c|c|c|}
\hline \multirow[t]{3}{*}{ Sera } & \multicolumn{4}{|c|}{ Duodenal Mucosa } \\
\hline & \multicolumn{2}{|c|}{ Infected with Duovirus } & \multicolumn{2}{|l|}{ Control } \\
\hline & Positive $^{1}$ & Negative $^{2}$ & Positive & Negative \\
\hline \multirow{6}{*}{$\begin{array}{l}\text { Acute sera } \\
\text { Convalescent sera } \\
\text { Convalescent sera } \\
\text { absorbed with } \\
\text { duovirus } \\
\text { Control sera } \\
\text { Reovirus antisera to } \\
1,2 \text {, and } 3\end{array}$} & 28 & 10 & 0 & 6 \\
\hline & 26 & 11 & 0 & 6 \\
\hline & & & & \\
\hline & 0 & 8 & \multirow{2}{*}{\multicolumn{2}{|c|}{$\begin{array}{l}\text { Not tested } \\
\text { Not tested }\end{array}$}} \\
\hline & 0 & 18 & & \\
\hline & 0 & 3 & \multicolumn{2}{|l|}{ Not tested } \\
\hline
\end{tabular}

Table I Immunofluorescence in biopsy specimens of duodenal mucosa from children with duovirus enteritis and controls

${ }^{1}$ Positive = fluorescence in epithelial cells.

${ }^{2}$ Negative $=$ no fluorescence in epithelial cells.

cells only when mucosa containing duovirus was reacted with acute or convalescent sera from patients known to have been infected with duovirus (fig. 1a). This fluorescence occurred with fluorescein-labelled antiserum to human IgM but not with similarly labelled antisera to IgG or IgA. Convalescent sera absorbed by incubation with 'purified' duovirus showed no fluorescence within epithelial cells in biopsy tissue containing duovirus (fig. 1b).

No fluorescence was seen in epithelial cells when control sera were incubated with duodenal mucosae containing duovirus, or when acute and convalescent sera were incubated with control mucosae containing no duovirus (table I).

The distribution of fluorescence along one villus is shown in figure 1a. Fluorescence attributed to the presence of duovirus was particulate in nature, and

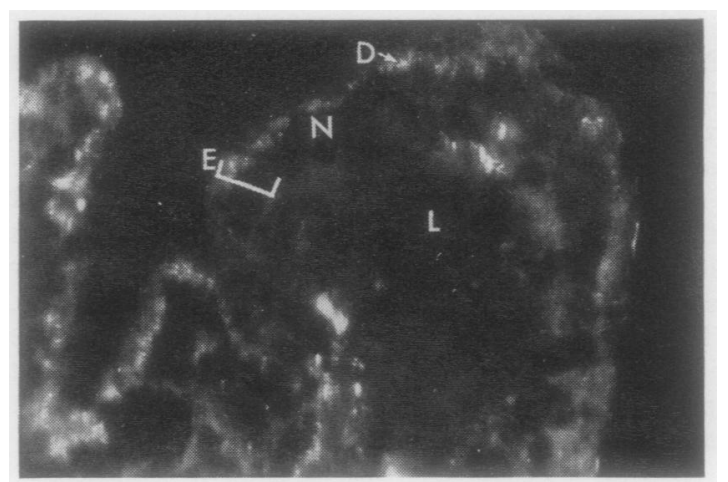

Fig 1a Particulate fluorescence in epithelial cells of duodenal mucosa from a child with acute enteritis due to duovirus. Original magnification $\times 500$ 


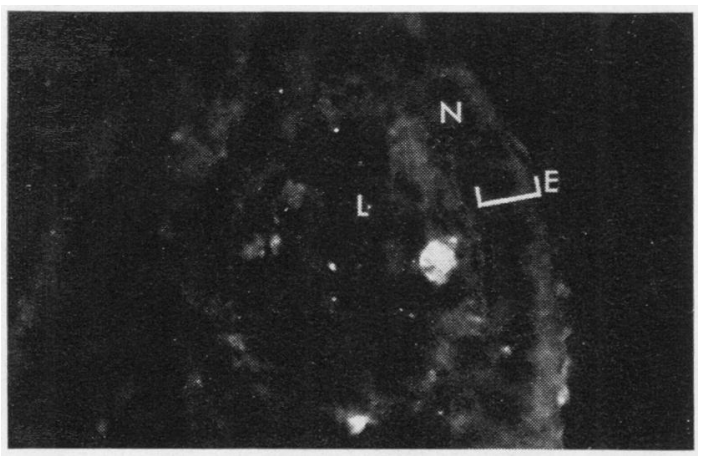

Fig 1b Abolition of particulate fluorescence in epithelial cells of duodenal mucosa after absorption of sera with duovirus antigen.

Original magnification $\times 500$

$\mathrm{D}=$ particulate fluorescence due to duovirus; $\mathrm{E}=$ epithelial cell layer; $\mathbf{N}=$ nucleus of epithelial cell; $\mathbf{L}=$ lamina propria

was located in a supranuclear position in the cytoplasm of duodenal epithelial cells. No fluorescence was seen in epithelial cell nuclei. Not all epithelial cells fluoresced in any one section. No specific fluorescence was seen in the cells of the lamina propria although diffuse non-specific fluorescence was observed in plasma cells in most sections. In each biopsy, distribution of epithelial cell fluorescence due to duovirus was patchy; some sections reacted strongly while others showed little specific fluorescence. The number of fluorescing epithelial cells present was influenced by duration of symptoms. Biopsy tissue obtained more than four days after the onset of symptoms showed few areas of epithelial cell fluorescence.

The patchy distribution of duovirus explains the inconsistent results with some sera. Of the total 75 reactions between mucosa containing duovirus and sera from duovirus-infected patients (table I), 54 showed positive fluorescence while 21 showed no fluorescence.

Mucosae containing duovirus showed fluorescence within epithelial cells when incubated with sera from the same patient, or with sera from other patients (table II). Only one homologous reaction (patient 5) was possible because most convalescent sera were collected after we ceased subjecting patients to duodenal biopsy.

Titres of paired acute and convalescent sera from two of the patients were estimated using consecutive sections from one biopsy specimen. Immunofluorescent titres were determined as the highest dilution of sera showing definite epithelial cell fluorescence. In both patients acute sera showed a

\begin{tabular}{ll}
\hline $\begin{array}{l}\text { Tissue from } \\
\text { Patient }\end{array}$ & $\begin{array}{l}\text { Epithelial Cell Fluorescence with Convalescent Serum } \\
\text { from Patient }\end{array}$ \\
\hline 1 & 5,11 \\
2 & $5,10,11,12,13$ \\
3 & $5,9,12$ \\
4 & $5,9,12$ \\
5 & $5,9,10,12$ \\
6 & $5,11,12$ \\
7 & $5,11,12$ \\
8 & 12 \\
\hline
\end{tabular}

Table II Immunofluorescence reactions between duodenal mucosa containing duovirus and convalescent sera from children with duovirus enteritis

titre of 1 in 4 for IgM antibodies, whereas paired convalescent sera showed a titre of 1 in 32 .

\section{Discussion}

Since the first report describing virus particles in epithelial cells of duodenal mucosa there has been rapid confirmation of the importance of this new virus in the aetiology of acute enteritis in childhood (Fletwett, Bryden, and Davies, 1973: Middleton, Szymanski, Abbott, Bortolussi, and Hamilton, 1974; Kapikian, Kim, Wyatt, Rodriguez, Ross, Cline, Parrott, and Chanock, 1974). Biopsy of the duodenal mucosa is no longer necessary to demonstrate this virus. Instead, virus particles can readily be seen by electron microscopy of negatively stained faecal extracts (Flewett et al, 1973; Bishop et al, 1974).

This study has used portions of duodenal mucosa already shown to contain duovirus by electron microscopy of ultrathin sections. Indirect immunofluorescence tests on this tissue located duovirus antigen only in the cytoplasm of epithelial cells of the villi. No identifiable duovirus was detected in cells of the lamina propria. Distribution of duovirus in epithelial cells was patchy, both in adjacent villi from the same biopsy, and in adjacent epithelial cells on the same villus. Duovirus was difficult to detect in mucosa obtained more than four days after the onset of symptoms.

Infection of children with duovirus was followed by the appearance of IgM antibodies in sera as early as two days after the onset of symptoms. The specific nature of the IgM response was shown by the absence of fluorescence in epithelial cells after absorption of positive sera with 'purified' duovirus. In two children an eightfold rise in duovirus antibody titre occurred during convalescence. This confirms the serological response to duovirus infection observed by Kapikian et al (1974) using immune electron microscopy and complement fixation.

Virus particles observed in all eight patients by electron microscopy appeared morphologically similar (Bishop et al, 1973b). Immunofluorescence 
reactions indicate that virus particles from different patients are also antigenically similar, since duovirus particles fluoresced when incubated with heterologous sera.

Duodenal tissue containing duovirus did not fluoresce with specific antisera to reovirus types 1, 2, and 3. This confirms the results of Kapikian et al (1974) and emphasizes that this virus is not a classical reovirus.

The results of this study give no information about the extent of duovirus infection along the gastrointestinal tract. It seems likely that mucosa of stomach and large intestine is seldom infected by this virus. Light microscopy shows little histological evidence of inflammation in gastric and rectal mucosa (Barnes and Townley, 1973). Immunofluorescence tests on epithelial cells scraped from intestinal mucosa show virus antigen in cells from the duodenum and upper jejunum, but not from the stomach, large bowel, or in one mesenteric lymph node (Middleton et al, 1974). It is suggested that duovirus replication in the human gut is confined to columnar epithelium of the duodenum and upper jejunum (Middleton et al, 1974).

Human duovirus bears a close morphological and antigenic resemblance to reo-like virus causing neonatal diarrhoea in calves ('Nebraska' calf scours) and mice (EDIM) (Bishop et al, 1974; Flewett, Bryden, Davies, Woode, Bridger, and Derrick, 1974; Kapikian et al, 1974). Experimentally induced infections in both animals showed light microscope changes similar to those observed in children (Adams and Kraft, 1967; Mebus, Stair, Underdahl, and Twiehaus, 1971). The extent of infection in the gut differed from that seen in children, since immunofluorescence techniques showed infection in epithelial cells of the ileum of calves (Mebus et al, 1971) and the ileum and large intestine of mice (Wilsnack, Blackwell, and Parker, 1969). No infection was seen in stomach mucosa in mice (Wilsnack et al, 1969). In both animals, immunofluorescence in the lamina propria could not be evaluated. Virus was located in blood, liver, spleen, and kidney in mice (Kraft, 1958).

The spread of duovirus infection beyond the epithelial cell layer in human infection remains to be proven. It seems possible that the prolonged high temperature observed in infected children is due to viraemia. Exact knowledge of the site of infection in vivo in children will help to elucidate development of immunity to this disease.

We thank Dr A. Williams and Dr C. S. Hosking for their valuable advice.

The work was supported by the Royal Children's Hospital Research Foundation Fellowship (G.P.D.), the Felton Bequest (R.F.B.), and the National Health and Medical Research Council of Australia (I.H.H., B.J.R.).

\section{References}

Adams, W. R., and Kraft, L. M. (1967). Electron-microscopic study of the intestinal epithelium of mice infected with the agent of epizootic diarrhea of infant mice (EDIM virus). Amer. J. Path, 51, 39-60.

Barnes, G. L., and Townley, R. R. W. (1973). Duodenal mucosal damage in 31 infants with gastroenteritis. Arch. Dis. Childh., 48, 343-349.

Bishop. R. F., Davidson, G. P., Holmes, I. H., and Ruck, B. J. (1973a). Evidence for viral gastroenteritis. New Engl. J. Med., 289. 1096-1097.

Bishop, R. F., Davidson, G. P., Holmes, I. H., and Ruck, B. J. (1973b). Virus particles in epithelial cells of duodenal mucosa from children with acute non-bacterial gastroenteritis. Lancet, 2 , 1281-1283.

Bishop, R. F., Davidson, G. P., Holmes, I. H., and Ruck, B. J (1974). Detection of a new virus by electron microscopy of faecal extracts from children with acute gastroenteritis. Lancet, 1, 149-151.

Flewett, T. H., Bryden, A. S., and Davies, H. (1973). Virus particles in gastroenteritis. Lancet, 2, 1497.

Flewett, T. H., Bryden, A. S., Davies, H., Woode, G. N., Bridger, J. C., and Derrick, J. M. (1974). Relation between viruses from acute gastroenteritis of children and newborn calves. Lancet, 2, 61-63.

Holmes, J. H., Ruck, B. R., Schnagl, R. D., Bishop, R. F., and Davidson, G. P. (1975). The virus of acute gastroenteritis in children, and a new group (duovirus) within the family Reoviridae. (In preparation).

Kapikian, A. Z., Kim, H. W., Wvatt, R. G., Rodriguez, W. J., Ross, S., Cline, W. L., Parrott, R. H., and Chanock, R. M. (1974). Reoviruslike agent in stools: association with infantile diarrhea and development of serologic tests. Science, 185, 1049 . 1052.

Kraft, L. M. (1958). Observations on the control and natural history of epidemic diarrhoea of infant mice (EDIM). Yale J. Biol. Med., 31, 121-137.

Mebus, C. A., Stair, E. L., Underdahl, N. R., and Twiehaus, M. J. (1971). Pathology of neonatal calf diarrhoea induced by a reolike virus. Vet. Path., 8, 490-505.

Middleton, P. J., Szymanski, M. T., Abbott, G. D., Bortolussi, R., and Hamilton, J. R. (1974). Orbivirus acute gastroenteritis of infancy Lancet, 1, 1241-1244.

Sainte-Marie, G. (1962). A paraffin embedding technique for studies employing immunofluorescence. J. Histochem. Cytochem., 10, 250-256.

Wilsnack, R. E., Blackwell, J. H., and Parker, J. C. (1969). Identification of an agent of epizootic diarrhea of infant mice by immunofluorescent and complement-fixation tests. Amer. J. vet. Res. 30, 1195-1204. 